be long standing. ${ }^{3}$ In our study more than a third of the abused women had been admitted five times or more.

The greater differences in admissions in the ages over 30 might be related to ongoing domestic violence. Several studies indicate that the risk of being the victim of wife beating is most pronounced in the fourth decade of life. ${ }^{124}$

The abused woman, in her exposed and desolate situation, does not always seek medical care for specific somatic diseases. ${ }^{3}$ The "battered wife syndrome" consists of somatic, psychosomatic, and psychiatric symptoms, and psychosocial support is an important reason for seeking hospital care.
Any physician should consider the possibility of ongoing domestic violence when confronted with a female patient lacking other obvious reasons for frequent hospital admissions.

1 Gayford JJ. Wife battering: a preliminary survey of 100 cases. BMJ $1975 ;$; : 194-7.

2 Gayford JJ. Battered wives. Med Science Law 1979;15:237-45.

3 Stark E, Flitcraft A, Frazier W. Medicine and patriarchal violence: the social construction of a "private" event. Int $f$ Health Serv 1979;9:461-93.

4 Appleton W. The battered woman syndrome. Ann Emerg Med 1980;9:84-91.

5 Jaffe P, Wolfe D, Wilson S, Zak L. Emotional and physical health problems of battered women. Can f Psychiatry 1986;31:625-9.

(Accepted 2 April 1992)
Department of

Environmental and

Preventive Medicine,

Wolfson Institute of

Preventive Medicine,

Medical College of St

Bartholomew's Hospital,

London

Nicholas Wald, professor

Rossana Stone, laboratory

manager

Institute of Epidemiology and Health Services

Research, Department of

Clinical Medicine,

University of Leeds,

Leeds LS2 9LN

H S Cuckle, professor of

reproductive epidemiology

Department of Obstetrics and Gynaecology, Royal

London Hospital, London

J G Grudzinskas, professor

Department of Obstetrics and Gynecology, Institute of Human Genetics, Sheba Medical Centre, Tel-Hashomer, Israel Gad Barkai, senior lecturer

\section{Istituto Ostetrico}

Ginecologico " $L$

Mangiagalli," Seconda

Clinica, University of

Milan, Milan, Italy

Bruno Brambati, head of

prenatal diagnosis unit

Division of Immunology, State Serum Institute, Copenhagen, Denmark Borge Teisner, associate professor

\section{Institute for Human}

Genetics, University of

Giessen, Giessen,

Germany

Walter Fuhrmann, professor

Correspondence to:

Professor Wald.

BMF 1992;305:28

\title{
First trimester concentrations of pregnancy associated plasma protein $A$ and placental protein 14 in Down's syndrome
}

Nicholas Wald, Rossana Stone, H S Cuckle,
J G Grudzinskas, Gad Barkai, Bruno Brambati,
Borge Teisner, Walter Fuhrmann

Brambati et al reported that first trimester maternal serum concentrations of pregnancy associated plasma protein A (PAPP-A) were low in pregnancies associated with fetal aneuploidy. Of 13 pregnancies associated with Down's syndrome, seven were reported as having values less than or equal to the fifth centile. ${ }^{1}$ To examine the matter further and explore whether PAPP-A might be useful in screening for Down's syndrome in the first trimester we measured its concentration in sera previously used for measuring $\alpha$ fetoprotein, unconjugated oestriol, and human chorionic gonadotrophin concentrations in the first trimester. ${ }^{2}$ At the same time we investigated the endometrial protein known as placental protein 14 (PP14) as a possible additional first trimester serum marker.

\section{Subjects, methods, and results}

Serum samples were available from 19 of the 22 women with Down's syndrome pregnancies previously studied and 101 of the 108 original controls. The samples had been collected between 9 and 12 weeks' gestation and had been stored frozen in serum banks (United Kingdom, three cases; Israel, four cases; Germany, five cases; Italy, seven cases). Samples had been taken routinely from antenatal patients in the United Kingdom and immediately before chorionic villus sampling in the other countries. Cases and controls were similar with respect to gestational age and duration of storage of the serum sample and were balanced with respect to country of origin. Analysis of placental protein 14 required a larger volume of serum, and sufficient material was available for only 11 cases of Down's syndrome and 64 controls. PAPP-A was measured by radioimmunoassay at the Royal London Hospital using a specific antibody (Dako, High Wycombe, United Kingdom) and purified PAPP-A prepared at the University of Odense, Denmark. Placental protein 14 was measured by radioimmunoassay with an antibody provided by $\mathrm{Dr} \mathrm{H}$ Bohn

We expressed results for PAPP-A in multiples of the control group median (MoM) using the overall median concentration for all the unaffected pregnancies without adjustment for gestation since there was no significant relation between concentration and gestational age. Concentration of PAPP-A was significantly lower in the women with Down's syndrome pregnancies than in the controls $(p<0.001$, Wilcoxon signed rank test) (figure). The median MoM was 0.23 (95\% confidence interval 0.17 to 0.46$)$ in the cases of Down's syndrome; 12 of the 19 women with affected pregnancies $(63 \%)$ had values below the 10 th centile value for the controls.
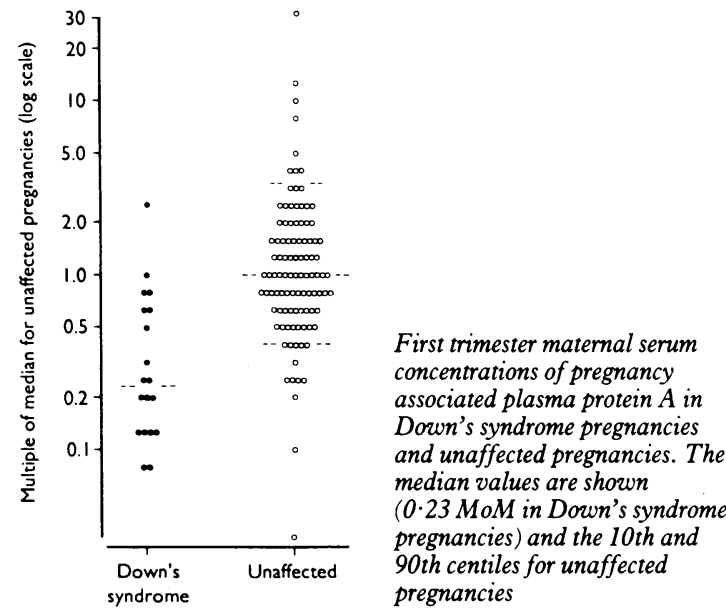

Placental protein 14 results were expressed in MoMs calculated from a weighted $\log$-linear regression of the median concentration for each completed week of pregnancy on gestational age. The concentrations in women with affected pregnancies were similar to those in women with unaffected pregnancies (median value $0.93 \mathrm{MoM}$ ) with almost total overlap.

\section{Comment}

Our results show that PAPP-A is a useful first trimester serum marker for Down's syndrome. Measurement of serum PAPP-A concentration together with other markers and the use of maternal age may form the basis of effective first trimester screening for Down's syndrome.

We thank Lynne George for performing the PAPP-A assays and Professor T Chard for suggesting the assay of PP14, which was performed in the department of reproductive physiology at St Bartholomew's Hospital. We also thank David Smith for help with computing.

1 Brambati B, Lanzani A, Tului L. Ultrasound and biochemical assessment of first trimester of pregnancy. In: Chapman M, Grudzinskas G, Chard T, eds. The embryo: normal and abnormal development and growth. London: SpringerVerlag, 1990:181-94.

2 Cuckle HS, Wald NJ, Barkai G, Fuhrmann WA, Altland K, Brambati B, et al. First trimester biochemical screening for Down's syndrome. Lance 1988;ii:851-2.

(Accepted 18 March 1992) 